\title{
Economic valuation of Lansa Mangrove Forest, North Sulawesi, Indonesia
}

\author{
CALVYN F.A. SONDAK ${ }^{\natural}$, ERLY Y. KALIGIS, ROBERT A. BARA \\ Department of Marine Science, Faculty of Fisheries and Marine Science, Universitas Sam Ratulangi. Kampus Unsrat Bahu, Manado 95115, North \\ Sulawesi, Indonesia. Tel.: +62-431-868027, `email: calvyn_sondak@unsrat.ac.id
}

Manuscript received: 13 November 2018. Revision accepted: 12 March 2019.

\begin{abstract}
Sondak CFA, Kaligis EY, Bara RA. 2019. Economic valuation of Lansa Mangrove Forest, North Sulawesi, Indonesia. Biodiversitas 20: 978-986. Mangrove forest gives many benefits and services to human and environment. Even though it contributes many benefits and services, coastal ecosystems threatened as one of the most critical ecosystems in the world. The study aims to estimate the economic value of ecosystem services provided by Lansa mangrove forest, Wori Sub-district, North Minahasa District, North Sulawesi Province, Indonesia. Here, we describe the use value (direct and indirect value) and non-use value (option and existence value), and emphasize the components of ecosystem services fish resources, firewood, coastal protection, biodiversity, carbon (C) removal and mangrove sustainability because these directly influence human welfare. Their market price calculated fish and $\mathrm{C}$ removal value. Coastal barrier and firewood were approached using the replacement cost method. Biodiversity value was calculated using Indonesia mangrove forest biodiversity value. Contingent Valuation method was used to find out people willing to pay for the sustainability of mangrove forest. Lansa mangrove forest total economic value (TEV) was IDR 4,431,197,603 or equal to US\$305,600 (US\$ $\left.1,959 \mathrm{ha}^{-1}\right)$. The success of this mangrove valuation has potentially large implications for future policy-making of its' ecosystem service values.
\end{abstract}

Keywords: Ecosystem service, mangrove forest, valuation

\section{INTRODUCTION}

Mangrove forest is one of the coastal ecosystems that can be found mostly in tropical regions. Indonesia has the largest mangrove forest area in the world. Data of Indonesian mangroves area was varied. Giesen (1993) reported that the Indonesia mangrove forest area was about 2.5 million ha, while 4.5 million ha claimed by Spalding et al. (1997). Meanwhile, recent data shows, mangrove forest area from 2016-2016 were 4.4 million ha, 3.7 million ha, and 3.9 million ha respectively (BPS 2017; MMAF 2017). In Indonesia, mangrove forest appeared in all 34 provinces. The largest area was found in Papua Province about 1.1 million ha, while Yogyakarta Province was the smallest about 40.10 ha (BPS 2017).

Mangrove forest gives many benefits and services to human and environment, such as coastal protection, food resources, species biodiversity and conservation (Vo et al. 2012). Even though, it contributes many benefits and services, coastal ecosystems threatened as one of the most critical ecosystems in the world. This condition due to the fact that approximately 340,000-980,000 ha mangrove forests destroyed annually (Murray et al. 2011), while Indonesia mangrove forest lost approximately $5.6 \%$ (204,698 ha) annually (BPS 2017). Globally, mangrove, seagrass, and salt marsh area lost to about $67 \%, 35 \%$ and $29 \%$ respectively (Pendleton et al. 2012). If this phenomenon continue, mangrove can lose the services that it provides for human and adjacent ecosystems.

Ecosystem services (ES) sustain, strengthen, and enrich various aspects of human life (Kumar and Muradian 2009). Natural ecosystems such as those associated with forest, freshwater, marine, or coastal environments interact with cultivated ecosystems (Wattage 2011). The term 'ecosystem services' is sometimes used interchangeably with 'environmental services' or 'ecological services' (FAO 2002). It has been defined as the array of processes and functions that benefit and support human welfare (Daily 1997; de Groot et al. 2002; MA 2005). These services have been classified as provisioning, regulating, supporting, cultural etc., which would otherwise remain hidden or unappreciated, can be revealed through estimates of value (Wilson et al. 2005). Only a few of these ecosystem services have been marketed, and integration has not been completed between the functions of ecological production and economic valuation within many key estuaries and coastal ecosystem services (Barbier et al. 2011).

Economic value is one way to define and measure worth based on a person's wants or preferences (King and Mazzota 2000). It is often considered the maximum amount an individual is willing to forego in other services and goods to obtain some services, products, or state of the world (Lipton et al. 1995). Economic valuation can also be described as an effort to allocate a quantitative value to the products and services provided by natural ecosystems (Costanza and Folke 1997; Daily et al. 1997). Recognizing the services and economic value of ecosystems is essential because of the great importance that humans place on their well-being, resource sustainability, and fairness in 
distribution (Costanza and Farber 2002).

Lansa mangrove forest is located in Wori Sub-district, North Minahasa District, North Sulawesi Province covered an area of 156 ha. Mangrove forest provides ecosystem services that can be used by humans and animals. Where an ecosystem's services can be identified and measured, it will often be possible to assign values to them by employing existing economic valuation methods (NRC 2004). The study aims to estimate the value of services provided by Lansa mangrove forest, Wori Sub-district, North Minahasa District, North Sulawesi Province, Indonesia. Several factors formed the basis for our study concept, such as gaps in our knowledge about marine coastal ecosystems services. This paper present ecosystem services valuation of Lansa mangrove forest. Here, we chose to emphasize the components of food resources, fuel, coastal protection, biodiversity, carbon (C) removal and mangrove sustainability because they directly influence human welfare.

\section{MATERIALS AND METHODS}

\section{Study site}

Lansa mangrove forest is located in the coast of North Minahasa District, North Sulawesi Peninsula, Indonesia

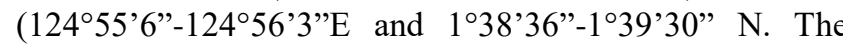

total area of mangrove forest is 156 ha. The map of study site is shown in Figure 1.

\section{Direct use value calculation}

Direct use value (DUV) for fishery and fuel was calculated by multiplied their quantity with the market price. Fish market price data was based on an interview to 16 local fishermen, while for firewood was six collectors. Data was collected using purposive sampling method with assumption that the respondents are mangrove resources user. Based on the interview, there was no market price for firewood as this firewood only uses for household activities. If there is no market price or final price for the service, replacement cost was used (Dixon and Sherman 1991; Woodward and Wui 2001; Permen KLH 2012; Barbier 2016). In this study, firewood market price was replaced with a $3 \mathrm{~kg}$ gas price. Fish and firewood value was based on Takarendehang et al. (2018).

\section{Indirect use value calculation}

Coastal protection value was based on Takarendehang et al. (2018) while for C removal, was computed by multiplied carbon trading price with $\mathrm{C}$ total content. In 2011, relevant markets were paying $\$ 3.90$ per ton temporary Certified Emission Rate, or tCER for carbon trade (Peters-Stanley et al. 2012).

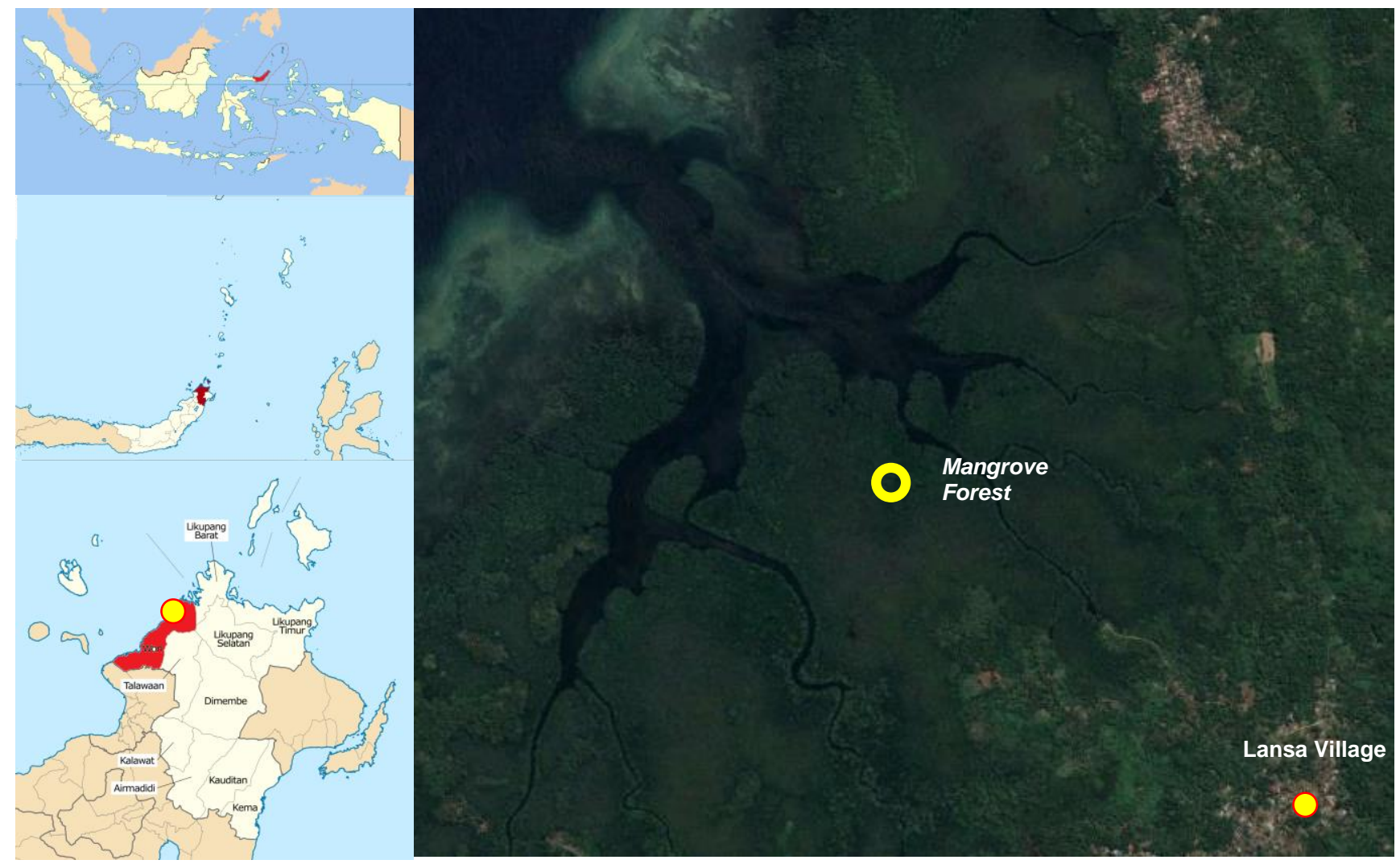

Figure 1. The study site of Lansa mangrove forest, North Sulawesi, Indonesia 


\section{Option value}

Mangrove forest biodiversity value was calculated according to Ruitenbeek (1992) value for Indonesia mangrove biodiversity value (USD 15/ha = Rp. 14,500 in September 2018) multiplied by the total area of mangrove. For mangrove wood potency was calculated by multiplied mangrove basal area with tree height.

\section{Existence value}

Existence value was estimated using the contingent valuation method (CVM). This method was based on the respondent's willingness to pay (WTP) on mangrove forest sustainable in their village. Questioners were used to get their willing to pay. Forty-two respondents randomly selected among the villagers with different backgrounds. They were given bid value IDR 10,000, IDR 15,000, IDR 20,000 and IDR 25,000 then was asked to bid among these values. Existence value was calculated by multiplying average of respondents WTP by the number of households.

\section{Total economic value}

Recognizing the total economic value (TEV) of services from mangrove forest is essential to meeting demands for human well-being, sustainability, and fairness in resource distribution (Costanza and Farber 2002). The concept of TEV generally entails both use-and non-use values when calculating the economic benefits of mangrove forest. Here in this study, there is no bequest value.

$$
\mathrm{TEV}=\mathrm{UV}(\mathrm{DUV}+\mathrm{IUV})+\mathrm{N}-\mathrm{UV}(\mathrm{OV}+\mathrm{XV}+\mathrm{BV})
$$

Where:

$$
\begin{array}{ll}
\text { UV } & \text { : Use Value } \\
\text { DUV } & \text { : Direct Use Value } \\
\text { IUV } & \text { Indirect Use Value } \\
\mathrm{N}-U V & : \text { Non-Use Value } \\
\mathrm{OV} & : \text { Option Value } \\
\mathrm{XV} & : \text { Existence Value } \\
\mathrm{BV} & : \text { Bequest Value }
\end{array}
$$

\section{Community structure study}

Mangrove community structure data was collected by stratified random sampling from six plots within mangrove forest. In each plot, a 10 x 10 quadrat were laid for trees sampling. Every tree within quadrat were counted, identified, and measured its diameter at breast high (dbh) at $\geq 1.3 \mathrm{~m}$. Mangrove tree structural indices including relative density, relative frequency, relative dominance, and importance value index (IVI) were estimated (Soerianegara and Irawan 2002).

$$
\begin{gathered}
\text { Rensity species -i } \\
\begin{array}{c}
\text { Density of all species } \\
\text { Frequency species-i }
\end{array} \\
\text { Relative frequency }=\text { - Frequency all species }
\end{gathered}
$$

$$
\begin{aligned}
& \text { Relative dominance }=\frac{\text { Dominance species-i }}{\text { Dominance value of all species }} \\
& \mathrm{IVI}=\text { relative density }+ \text { relative frequency }+
\end{aligned}
$$
dominance relative

\section{Mangrove biomass}

Above ground biomass was calculated by multiplying wood density with allometric equation and tree dbh.

$$
\mathrm{W}_{\text {top }}=\rho^{*} 0.251 \mathrm{dbh}^{2.46}(\text { Komiyama et al. 2005) }
$$

Where:

$\mathrm{W}_{\text {top }}$ : is above-ground biomass

$\rho \quad:$ is wood density

$\mathrm{dbh}:$ is diameter at breast height at $1.3 \mathrm{~m}$

\section{Mangrove carbon and carbondioxide $\left(\mathrm{CO}_{2}\right)$ content}

Carbon content in mangrove was estimated base on the tree biomass (above ground biomass) (IPPC 2006). C concentration in organic matter is 0.47 (47\%). Carbon content in mangrove tree then estimated by multiplying 0.47 to above-ground biomass.

$$
\mathrm{C}_{\text {con }}=0.47 \times \mathrm{B}
$$

Where:

$\mathrm{C}_{\text {con }}$ : C concentration

0.47 : percentage of organic matter

B : Biomass

The potential amount of $\mathrm{CO}_{2}$ that could be sequestered then was calculated by multiplying Carbon (C) by the amount of $\mathrm{CO}_{2}$ measured in 1 gram of dry plant material which is 3.67 (Mudiyarso 1999).

$$
\begin{aligned}
& \mathrm{WCO}_{2}=\mathrm{C} \times 3.67 \\
& \text { Where: } \\
& \mathrm{WCO}_{2}: \mathrm{CO}_{2} \text { potential sequestration } \\
& \mathrm{C}: \text { Carbon concentration } \\
& 3.67 \quad: \text { amount of } \mathrm{CO}_{2} \text { in } 1 \mathrm{~g} \text { of dry plant material }
\end{aligned}
$$

\section{RESULTS AND DISCUSSION}

\section{Use value}

According to TEEB (2010), Use Value can be associated with private of quasi-private good, for which market price usually exist and can be grouped into direct use value and indirect use value. This study found that mangrove forest use value (direct use and indirect use value) were fishes, firewood, carbon removal, and coastal barrier. Total direct use value was 1,789,629,000 while indirect use value was 2,586,190,270 (Table 3). Direct Use Value (DUV) represents services that are intended for immediate consumptive or non-consumptive purposes (e.q fishes, firewood) while the Indirect Use Value (IUV) indicates 
the intermediate inputs associated with the manufacture of end products and services for human consumption (e.q coastal barrier, carbon removal) (MA 2005).

Many Indonesia coastal inhabitants have used services from mangrove for a long time for firewood, charcoal, tannin, dyes, food, beverages, medicine, pole, and timber (Kusmana 2014). Similarly, some Lansa village inhabitants relies on their daily income from services offer by mangrove forest. Fishes and firewood were used for food, cooking, and sell to the market but mostly the community use for their daily use. Fishes mostly dominated by grouper (Epinephelus sp.), these fishes mostly sell to support family income and the rest consume as food for all family member. Firewood mainly used as fuel for their cooking activities and trade in the market. It was found that age level, income, and job are strongly affected by the dependency on mangrove (Mojiol et al. 2016). This was an assumed factor that affects the utilization of mangrove forest services by the villagers.

As the risk of natural disasters such as cyclones and tsunami increasing in North Sulawesi, mangrove forest can be a barrier to reduce the hazardous impact on many North Sulawesi coastal villages including Lansa village. With a total coverage area of 156 ha, Lansa mangrove can protect the coast line and the communities of this area. Mangrove provides coastal barrier and protection for the coastal community in terms of decrease the wave and wind power (Mazda et al. 1997; Kathiresan and Rajendran 2005; Spalding et al. 2014; Barbier 2016). Moreover, mangrove can reduce the impact of storm and tsunami that can save coastal communities from property damage and get injury even death (Koch et al. 2009; Barbier 2016). As an example, an area of Rhizophora sp. $400 \mathrm{~m}$ wide with a density of 0.2 trees $\mathrm{m}^{-2}$, and a stem diameter of $15 \mathrm{~cm}$ can minimize the tsunami inundation depth by $30 \%$ when $3 \mathrm{~m}$ tsunami wave occur (Yanagisawa et al. 2009). Mangrove value as the coastal barrier was approached using replacement cost method where calculation was done by substitute mangrove forest value as the coastal barrier with construction of breakwater. Current estimation value was IDR 2,583,300,000 (Table 4) but with prediction that natural disaster events increase on its frequency and intensity in the future, this value could be higher.

Climate change and rising atmospheric $\mathrm{CO}_{2}$ levels have become serious environmental issues. Present day the study on the role of coastal vegetation (i.e. seagrass, salt marsh, seaweed bed, mangrove) to combat climate change by carbon dioxide mitigation has been increasing (Chmura et al. 2003; Duarte et al. 2005; Donato et al. 2011; Sondak and Chung 2015; Sondak et al. 2017). Mangrove plays an important role in carbon fixation that can help improve the capacity to absorb atmospheric $\mathrm{CO}_{2}$ by sequester through photosynthesis. Lansa mangrove forest can remove $\mathrm{C}$ and sequester $\mathrm{CO}_{2}$ about $13.94 \mathrm{t} \quad \mathrm{C}$ and $51.11 \quad \mathrm{t} \quad \mathrm{CO}_{2}$ respectively. This result indicates that $55 \mathrm{t} \mathrm{CO}_{2}$ have an economic value about IDR 2,890,270 or US\$ 199. By comparison, the economic value attributed to $\mathrm{CO}_{2}$ sequestration within Philippine coral reefs is $\$ 8.4$ million over 464,090 ha, or $\$ 18.10$ ha-1 (Samonte-Tan and Amedilla 2004).
Table 1. Biomass, total potential of Carbon (C) and Carbondioxide $\left(\mathrm{CO}_{2}\right)$

\begin{tabular}{lccc}
\hline Species & $\begin{array}{c}\text { Total } \\
\text { biomasa } \\
\left(\mathbf{t o n} \mathbf{h}^{-1}\right)\end{array}$ & $\begin{array}{c}\text { Total } \\
\text { karbon } \\
\left(\mathbf{t o n} \mathbf{h}^{-1}\right)\end{array}$ & $\begin{array}{c}\text { Total } \\
\mathbf{C O}_{\mathbf{2}} \\
\left(\mathbf{t o n}^{\mathbf{1}}\right)\end{array}$ \\
\hline Avicennia marina (Forssk.) Vierh. & 3.37 & 1.59 & 5.83 \\
Rhizophora sp. & 20.48 & 9.64 & 35.34 \\
Xylocarpus granatum J.Koenig & 4.49 & 2.12 & 7.76 \\
Sonneratia alba Sm. & 5.31 & 0.56 & 2.06 \\
Ceriops tagal (Perr.) C.B.Rob. & 0.07 & 0.03 & 0.12 \\
Total & 33.72 & 13.94 & 51.11 \\
\hline
\end{tabular}

Rhizophora sp. has the highest total biomass (20.48 $\mathrm{t}$ $\mathrm{ha}^{-1}$ ) (Table 1) compare to other mangrove species (Table 1). $\mathrm{C}$ total and $\mathrm{CO}_{2}$ total removal and sequestrate were dominated by Rhizophora sp., 9.64 t $\mathrm{C}$ and $35.34 \mathrm{t} \mathrm{CO}_{2}$ correspondingly. C. tagal indicated to have the lowest biomass, $\mathrm{C}$ total and $\mathrm{CO}_{2}$ total among these five species. Biomass and carbon stock affected by mangrove tree diameter and density (Eusop et al. 2018). Our data from the mangrove community structure support this statement as Rhizophora sp. has the highest density and basal area (Table 5). We found as biomass increase carbon stock in mangrove also increase. This condition could be explained why Rhizophora sp. has the highest potency of $\mathrm{C}$ removal it is because this species has the highest biomass among five species found.

\section{Non use value}

Non use value is value that do not involve direct and indirect uses of ecosystem services (TEEB 2010). These values can be categorized in option value, existence value, and bequest value.

\section{Option value}

The option value $(\mathrm{OV})$ is the value that people place on having the possible opportunity to enjoy something in the future, such as biodiversity (King and Mazzota 2000). Mangrove option value was approached from its biodiversity value. Lansa mangrove forest biodiversity value was IDR 56,550,000 (Table 4). During the study, some terrestrial fauna, such as birds, butterflies, insects) as well as mangrove fauna, such as crabs, shrimps, mollusks, crustacean spotted in this area. This condition can be assumed that the area has high biodiversity.

Mangrove ecosystem is well known as one of most diverse flora and fauna that come from land and ocean as they provide foods, habitat, and shelter for them. The Indonesian mangrove consists of 202 species, (Kusmana 1993; Noor et al. 2006), while marine fauna, such asgastropods, bivalves, and crustaceans consist of 118 species (Kartawinata and Walujo 1977; Budiman and Darnaedi 1984; Pramudji 2001) and terrestrial fauna, such as mammals, reptiles, amphibians, and birds consist of 147 species (LPP Mangrove 2000). Fauna mangrove can be found in every part of mangrove ecosystem such as, in mangrove tree and canopy (birds, insects, mammals, and reptiles), roots (tunicates, sponges, algae, and bivalves), space between roots (prawns, crabs and fishes) (Nagelkerken et al. 2008). As mangrove provide high 
biodiversity, it is urgent to protect from losing its value. According to de Groot et al. (2012), marine ecosystem services have sustained degradation and a loss of biodiversity. This condition has led to their decreased functioning and resilience, ultimately risking the continuity of flow in supplying both present and future generations. The diversity of flora and fauna and also economic values should be evaluated to reserve this resources loss.

\section{Existence value}

The existence value (XV) is the value people assign to knowing that something is available, even if they will never see or use it, such as mangrove sustainability (King and Mazzota 2000). Table 2 presents data analysis of respondents' willingness to pay for sustaining mangrove forest. All 42 respondents answered that they would contribute for the existence of mangrove forest. with WTP values ranging from IDR 10,000 to 25,000 . The highest respondent bidding value was IDR 25,000 as 23 out of 42 willing to pay this amount of money for the sustainability of mangrove forest. The existence value for mangrove forest was IDR 7,828,333.

The concept of Willingness to Pay (WTP) offers a measure of how financially supportive humans would be toward implementing a given policy change to protect nature or environmental quality, with one goal being the improvement of their well-being (Goulder and Kennedy 2009). When both TEV and WTP are applied, ecological ecosystems can be translated into the language of economics to assess the monetary value of goods and services (monetization). In some cases, markets indicate individuals' true WTP as defined above, such as the market price of tomato might indicate what consumers are willing to pay for that product (Goulder and Kennedy 2009). The results of this study cannot be said to be represent respondents desire to pay WTP, but it is important to note that this WTP study is a preliminary study conducted to obtain feedback from the public on the value of the services provided by the mangrove forest services. The results are expected to be used as a reference for future studies such as used bid value for contingent valuation study in mangrove forest.

\section{Total economic valuation (TEV)}

Total economic value (TEV) is the sum of Use Value (Direct Value and Indirect Value) and Non-Use Value (Option Value, Existence Value, and Bequest Value). Mangrove forest TEV in this study was IDR $4,431,197,603$. Non Use Value has the biggest contribution on TEV as it contributed $58.36 \%$ followed by use value $(40.18 \%)$, optional value $(1.28 \%)$ and existence value $(0.18 \%)$ respectively (Table 3$)$.

Total economic value (TEV) was calculated by sum of the direct, indirect, option and existence values. The economic valuation of coastal resources and marine ecosystems is a complementary tool for decision-making and implementation of public policies related to the conservation and sustainable exploitation of renewable resources and their ecosystems (Vasquez et al. 2014). Total economic value (TEV) represents the sum of all types of use and non-use values for a good or service (King and
Mazzota 2000). The ecosystem services value were grouped into direct value, indirect value, and option value Direct use value (DUV) focuses on services intended for immediate consumptive or non-consumptive purposes while indirect use value (IUV) comprises the intermediate inputs associated with the manufacture of end products and services for human consumption (MA 2005).

Lansa mangrove forest TEV was approximately IDR $4,431,197,603$ or equal to US\$ 305,600 (US\$ $1,959 \mathrm{ha}^{-1}=1$ US\$ = IDR 14,500 in September 2018). Globally, the average annual revenues per hectare for other coastal ecosystems have been approximately $\$ 2,287$ to $\$ 16,283$ for seagrasses (Dirhamsyah 2007; Baldwin 2009), \$983 to $\$ 51,000$ for wetlands (Emerton and Kakulandala 2003; Brander et al. 2006; Tong et al. 2007; Costanza et al. 2008), $\$ 15,000$ to $\$ 100,000$ for coral reefs (Senprachawong 2004; Baldwin 2009), $\$ 232$ to $\$ 91,000$ for mangroves (Sathirathai and Barbier, 2001; Spurgeon, 2002; Gunawardena and Rowan 2005; Corps 2007; Aburto-Oropeza et al. 2008; Hussain and Badola 2008; Baldwin 2009), and \$8,565 for natural seaweed beds (Wahyudin 2007).

Table 2. Total WTP suggested by respondents to sustain mangrove forest

\begin{tabular}{lll}
\hline Bidding value & Frequency & Total WTP Y \\
\hline IDR 10,000 & 13 & 130,000 \\
IDR 15,000 & 5 & 45,000 \\
IDR 20,000 & 1 & 20,000 \\
IDR 25,000 & 23 & 575,000 \\
Total & 42 & 770,000 \\
Average & & $18,333.33$ \\
\# of Household & & 427 \\
Existence Value & & $7,828,333$ \\
\hline
\end{tabular}

Table 3. Mangrove forest total economic value, North Sulawesi, Indonesia

\begin{tabular}{lll}
\hline Ecosystem service group & $\begin{array}{l}\text { Value } \\
\text { (IDR) }\end{array}$ & $\begin{array}{l}\text { Percentage } \\
(\mathbf{\%})\end{array}$ \\
\hline Direct value & $1,780,629,000$ & 40.18 \\
Indirect value & $2,586,190,270$ & 58.36 \\
Optional value & $56,550,000$ & 1.28 \\
Existence value & $2,890,270$ & 0.18 \\
Total & $4,431,197,603$ & 100 \\
\hline
\end{tabular}

Table 4. Lansa mangrove forest economic valuation, North Sulawesi, Indonesia

\begin{tabular}{|c|c|c|}
\hline $\begin{array}{l}\text { Ecosystem } \\
\text { services }\end{array}$ & Use & $\begin{array}{l}\text { Economic value } \\
\text { (IDR) }\end{array}$ \\
\hline Coastal barrier & $\begin{array}{l}\text { Protection from abrasion, } \\
\text { waves, tsunami }\end{array}$ & $2,583,300,000 *$ \\
\hline Fire-wood & Fuel for cooking & $259,200,000 *$ \\
\hline Fish source & Family income & $1,521,429,000 *$ \\
\hline Biodiversity & Flora and Fauna diversity & $56,550,000$ \\
\hline $\begin{array}{l}\text { Carbon } \\
\text { removal }\end{array}$ & $\begin{array}{l}\text { Help to combat climate } \\
\text { change }\end{array}$ & $2,890,270$ \\
\hline $\begin{array}{l}\text { Willingness to } \\
\text { Pay }\end{array}$ & Mangrove sustainability & $7,828,333$ \\
\hline Total & & $4,431,197,603$ \\
\hline
\end{tabular}

Note: *Based on Takarendehang et al. (2018) 
Table 5. Lansa mangrove forest community structure

\begin{tabular}{|c|c|c|c|c|c|c|c|c|}
\hline Species & $\begin{array}{l}\text { Local } \\
\text { name }\end{array}$ & Common name & $\mathbf{N i}$ & $\begin{array}{c}\mathbf{K} \\
\left(\mathbf{m}^{2}\right)\end{array}$ & $\begin{array}{c}\text { BA } \\
\left(\mathbf{c m}^{2}\right)\end{array}$ & $\begin{array}{l}\text { KR } \\
(\%)\end{array}$ & $\begin{array}{l}\text { DR } \\
(\%)\end{array}$ & IVI \\
\hline Avicennia marina (Forssk.) Vierh. & Api api & Grey mangrove & 36 & 0.06 & $1,411.91$ & 13.95 & 27.15 & 66.10 \\
\hline Rhizophora sp. & Lolaro & Stilt mangrove & 134 & 0.22 & $1,495.45$ & 51.94 & 28.76 & 105.69 \\
\hline Xylocarpus granatum J.Koenig & Kira-kira & Cannonball mangrove & 65 & 0.11 & $1,356.31$ & 25.19 & 26.08 & 76.27 \\
\hline Sonneratia alba $\mathrm{Sm}$. & Posi-posi & Apple mangrove & 11 & 0.02 & 911.91 & 4.26 & 17.54 & 38.47 \\
\hline Ceriops tagal (Perr.) C.B. Rob. & Ting & Rib-fruited yellow mangrove & 12 & 0.02 & 24.84 & 4.65 & 0.48 & 13.46 \\
\hline Total & & & 258 & 0.43 & $5,200.42$ & 100 & 100 & 300 \\
\hline
\end{tabular}

Note: $\mathrm{Ni}$ = \#Mangrove Stand; $\mathrm{K}=$ Density; $\mathrm{BA}=$ Basal Area; $\mathrm{Kr}=$ Relative Density; DR = Relative Dominance; IVI = Important Value Index

There were some positive results obtained from this study, among others, the results obtained from this study at least can be said to have described the community's desire to provide value to the services provided by the mangrove forest. In addition, this study can also be said to succeed to inform the public about the services provided by the mangrove forest. Moreover, this study also increased public awareness for the conservation and sustainability of the mangrove forest in the future.

\section{Ecosystem service}

This study found that Lansa mangrove forest provides ecosystem services for human well-being. These services are mangrove forest as a coastal barrier, provide fishes, firewood, conserve biodiversity, and removing carbon to mitigate climate change. This study also can provide the monetary value of these services. The total monetary value for coastal barrier was IDR 2,583,300,000. Per-annum economic values for fire-wood were IDR 259,200,000 and IDR 1,521,429,000 for fish. An annual value for biodiversity was IDR 56,550,000 and potential C removal value was IDR 2,890,270. People willing to pay (WTP) for mangrove forest sustainability, was IDR 7,828,333. The annual TEV for mangrove forest was approximately IDR 4,431,197,603 (Table 4).

Ecosystems and species biodiversity provide a wide range of services that sustain, strengthen, and enrich various components of human well-being (Kumar and Muradian 2009). The services derived from marine plants such as seaweeds, kelps, seagrasses, and mangroves attract public attention because of their benefits to human life. The support services associated with ecosystems are often greatly undervalued by society because most are not traded in formal markets and are not easily quantified (Daily 1997; Vo et al. 2012). Only a few of these ecosystem services have been marketed to date, and integration has not been completed between the functions of ecological production and economic valuation within many key estuaries and coastal ecosystem services (Barbier et al. 2011).

Moreover, their unique characteristics mean that although humans might recognize them, they are generally discounted, have no assigned price, and therefore remain outside of market domains (Kumar and Muradian 2009).
This lack of valuation leads to treating these services as public policy issues when entering into collective decisionmaking (Robbins 2005). However, the valuation of ecosystem services (ES) is becoming an increasingly important contributor to policy and decision-making on scales that range from local to global (Fisher et al. 2011).

\section{Mangrove forest ecosystem service economic valuation}

Lansa mangrove forest offers services to the surrounding inhabitant. These services give not only ecological benefits, but also economic benefits to the village community. These services include coastal protection, biodiversity, firewood, fishes, C removal and sustainability. By knowing ecosystem services resource management can help the local government, stakeholders and decision makers to decide the best resource management action for mangrove (Kaplowitz 2001). Despite using these services, however, these services should be protected from loss. Protection can be done through the valuation of mangrove forest ecosystem services. The value of ecosystem service is the community willing to pay for keeping natural resources or products from being the loss (TEEB 2010). The value of a product can be defined and measured in many ways. For example, the results of economic analysis can be used to promote effective strategies for valuating ecosystem services already being rendered from mangrove but which have not yet been fully captured on commercial markets (Costanza et al. 1997; Beaumont et al. 2008). This approach provides a powerful tool for sustainable development because it can illustrate how dependent a particular economy is on that ecosystem and show what would be lost if that ecosystem were not protected (Lange and Jiddawi 2009). In the absence of such a valuation, those services risk being regarded as free and, thus might not receive adequate consideration as part of a management strategy (Beaumont et al. 2008).

\section{Mangrove community structure}

Five mangrove species were found within six plots, Avicennia marina, Rhizophora sp., Sonneratia alba, Xylocarpus granatum, and Ceriops tagal (Table 5). Total mangrove area was 156 ha and the distance from the sea to coastline approximately $1,500 \mathrm{~m}$. The highest absolute 
density and relative density was found in Rhizophora sp. $\left(0.22 \mathrm{ind} / \mathrm{m}^{2}\right.$ and $\left.51.94 \%\right)$ and the lowest was $S$. alba $(0.02$ $\mathrm{ind} / \mathrm{m}^{2}$ and $\left.4.26 \%\right)$. Similarly, the highest relative dominance value (DR) was found in Rhizophora sp $(28.76 \%)$ while the lowest was in $C$. tagal $(0.48 \%)$. In addition, this study found that Rhizophora sp. have the highest IVI (105.69) while the lowest was $C$. tagal (13.46).

Mangrove tree density was $0.43 \mathrm{~m}^{2}$ which is 4,300 trees $\mathrm{ha}^{-1}$. Based on the criteria of mangrove health status from the Ministry of Environmental (KLH) (2004), mangrove forest in this area was considered in good condition $(\geq 1500$ tree $\mathrm{ha}^{-1}=$ good). We found that the local wisdom plays the important role in local community perspective on mangrove sustainability. Together with the village government, the communities protect this forest. The local government established a village regulation to conserve and preserve their mangrove and socialized it to the communities. As a result, the communities have high awareness of mangrove conservation and sustainability. Local communities have a high contribution to mangrove conservation as they realize that mangrove are directly supporting their livelihood (Badola et al. 2012; Basyuni et al. 2016). Important value index (IVI) shows one species influence into the community. Density is the total amount of species within one particular area (Odum 1998). This study shows that Rhizophora sp has the highest IVI while C. tagal was the lowest. IVI shows the role of one species to its community, so it can be said that in Lansa village mangrove forest, Rhizophora sp has the highest role in the mangrove community compare to other species. The greater IVI of a species leads to the greater its role in the community (Soegianto 1994).

In conclusion, the success of mangrove valuation has potentially board implications for future policy-making. Monetary value is a currency that is universally understood by policy makers, economists, scientists and politicians alike. Considered together these estimates of mangrove forest economic values might help focus management priorities. For example, the estimates could suggest that managing ecosystem services to food production for food sustainability, more sensible management option toward potential $\mathrm{CO}_{2}$ sequestration with the aim of mitigating climate change. Although some ecosystem attributes can be valued during this study, the current study does not value all the services of mangrove forest. Thus, an assessment of what can and cannot be valued, and what problems remain after existing methods are important in the future study.

\section{ACKNOWLEDGEMENTS}

We would like to thank Sam Ratulangi University for Riset Dasar Unggulan Unsrat (RDUU) research grant SP DIPA-042.01.2.400959/2018 for fully funded this study. Thank you also delivered for all the team members for makes this study success.

\section{REFERENCES}

Aburto-Oropeza O, Ezcurra E., Danemann G, Valdez V, Murray J, Sala E. 2008. Mangroves in the Gulf of California increase fishery yields. Proc Nat Acad Sci USA 105 (30): 10456-10459.

Badan Pusat Statistik (Statistic Indonesia). 2017. Statistic of Marine and Coastal Resources. Badan Pusat Statistik. Jakarta. [Indonesian]

Badola R, Barthwal S, Hussain SA. 2012. Attitudes of local communities towards conservation of mangrove forests: A case study from the east coast of India. Est Coast Shelf Sci 96:188-196.

Baldwin K. 2009. A Marine Space-use Information System for the Grenadine Islands: A Basis for Collaborative Planning and Management. [Dissertation] Centre for Resource Management and Environmental Studies, University of the West Indies, Cave Hill Campus, Barbados.

Barbier EB, Hacker SD, Kennedy C, Koch EW, Stier AC, Silliman BR. 2011. The value of estuarine and coastal ecosystem services. Ecol Monogr 81 (2): 169-193.

Barbier EB. 2016. The protective service of mangrove ecosystem: A review valuation methods. Mar Poll Bull 109 (2): 676-681.

Basyuni M, Rouf RA, Saragih M, Asbi AM, Yuriswan W. 2016. Local wisdom and mitigation action to maintain secondary mangrove forest: A case study of Jaring Halus Village in Langkat, North Sumatra, Indonesia. Adv Soc Sci Edu Hum Res 81:551-555

Beaumont NJ, Austen MC, Mangi SC, Townsend M. 2008. Economic valuation for the conservation of marine biodiversity. Mar Poll Bull 56: 386-396.

Brander LM, Flora RJGM, Vermaat JE. 2006. The empiric's wetland valuation: a comprehensive summary and a meta-analysis of the literature. Environ Resource Econ 33: 223-250.

Budiman A, Darnaedi D. 1984. Struktur komunitas moluska di hutan mangrove Morewali, Sulawesi Tengah. Prosiding Seminar II Ekosistem Mangrove. MAB-LIPI, Bogor. [Indonesian]

Chmura GL, Anisfield SC, Cahoon DR, Lynch JC. 2003. Global carbon sequestration in tidal, saline wetland soils. Global Biogeochem Cycle 17:1111. doi: 10.1029/2002GB001917

Corps C. 2007. Mangrove conservation vs. shrimp farming in Thailand: case study 2. Vancouver valuation accord. www.vancouveraccord.org.

Costanza R, d'Arge R, de Groot R, Farber S, Grasso M, Hannon B, Kimburg K, Naeem S, O’Neil RV, Paruelo J, Raskin RG, Sutton P, van den Belt M. 1997. The value of the world's ecosystem services and natural capital. Nature 387: 253-260.

Costanza R, Farber S. 2002. Introduction to the special issue on the dynamics and value of ecosystem services: integrating economic and ecological perspectives. Ecol Econ 41: 367-373.

Costanza R, Folke C. 1997. Valuing ecosystem services with efficiency, fairness and sustainability as goals. Island Press, Washington, DC.

Costanza R, Perez-Maqueo O, Martinez ML, Sutton P, Anderson SJ, Mulder K. 2008. The value of coastal wetlands for hurricane protection. Ambio 37 (4): 241-248.

Daily GC, Alexander S, Ehrlich PR, Goulder L, Lubchenco J, Matson PA, Mooney HA, Postel S, Schneider SH, Tilman D, Woodwell GM. 1997. Ecosystem services: benefits supplied to human societies by natural ecosystem. Issues Ecol 2: 1-21.

Daily GC. 1997. Valuing and safeguarding Earth's life support system. Island Press, Washington, DC.

de Groot R, Brander L, van der Ploeg S, Costanza R, Bernard F, Braat L, Christie M, Crossman N, Ghermandi A, Hein L, Hussain S, Kumar P, McVittie A, Portella R, Rodriguez LC, Brink P, van Beukering P. 2012. Global estimates of the value of ecosystems and their services in monetary units. Ecosyst Serv 1 (1): 50-61.

de Groot R, Wilson MA, Boumans RMJ. 2002. A typology for the classification description and valuation of ecosystem functions, goods and services. Ecol Econ 41: 393-408.

Dirhamsyah. 2007. An economic valuation of seagrass ecosystems in East Bintan, Riau Archipelago, Indonesia. Oseanologi \& Limnologi di Indonesia 33: 257-270. [Indonesian]

Dixon JA, Sherman PB. 1991. Economics of protected areas: a new look at benefits and costs. Earthscan, London 
Donato DC, Boone Kauffman J, Murdiyarso D, Kurnianto S, Stidham M, Kanninen M. 2011. Mangrove among the most carbon-rich forests in the tropics. Nat Geosci 4: 293-297

Duarte, CM, Middelburg JJ, Caraco N. 2005. Major role of marine vegetation on the oceanic carbon cycle. Biogeosciences 2: 1-8.

Emerton L, Kekulandala LDCB. 2003. Assessment of the economic value of Muthurajawela Wetland. Occasional Paper of the IUCN, Sri Lanka.

Eusop MEM, Ismail MH, Kasim MRM. 2018. Estimating aboveground biomass and carbon stocks of mangrove forests in Kuala Sepetang, Perak. Malays For 81 (2): 145-153.

FAO. 2002. Livestock: intensification and its risks. In: World Agriculture Towards 2015/2030. Summary Report. Food and Agriculture Organization, Rome.

Fisher B. Bateman I. Turner RK. 2011. Valuing ecosystem services: benefits, values, space and time. The United Nations Environment Programme Working Paper Series 3: 1-11.

Giesen W. 1993. Indonesia's Mangroves: An update on remaining area and main management issues. In Seminar "Coastal Zone Management of Small Island Ecosystems", Ambon, 7-10 April 1993. [Indonesian]

Goulder LH, Kennedy D. 2009. Interpreting and estimating the value of ecosystem services. Stanford University, Stanford, CA, USA.

Gunawardena M, Rowan JS. 2005. Economic valuation of mangrove ecosystem threatened by shrimp aquaculture in Sri Lanka. Environ Manag 36 (4): 535-550.

Hussain SA, Badola R. 2008. Valuing mangrove ecosystem services: linking nutrient retention function of mangrove forests to enhanced agroecosystem production. Wetlands Ecol Manage 16:441-450.

IPCC (Intergovernmental Panel on Climate Change). 2006. IPCC Guidelines for National Greenhouse Gas Inventories - A primer, Prepared by the National Greenhouse Gas Inventories Programme. In: Eggleston HS, Miwa K, Srivastava N, Tanabe K. (eds.). The Institute for Global Enviromental Strategies (IGES), Japan.

Kaplowitz M. 2001. Assessing mangrove products and services at the local level: the use of focus groups and individual interviews. Lands Urb Plan 56: 53-60.

Kartawinata K, Walujo EB. 1977. A preliminary study of the mangrove forest on Pulau Rambut, Jakarta Bay. Mar Res Indon 18: 119-129

Kathiresan K, Rajendran N. 2005. Coastal mangrove forests mitigated tsunami. Est Coast Shelf Sci 65 (3): 601-606.

Keputusan Menteri Negara Lingkungan Hidip (KLH) No. 201 Tahun 2004. 2004. Kriteria baku dan pedoman penentuan kerusakan mangrove. [Indonesian]

King DM, Mazzota M. 2000. Ecosystem valuation. U.S. Department of Agriculture, Natural Resources Conservation Service, and National Oceanographic and Atmospheric Administration, Washington DC..

Koch EW, Barbier EB, Silliman BR, Reed DJ, Perillo GME, Hacker SD, Granek EF, Primavera JH, Muthiga N, Polasky S, Halpern BS, Kennedy CJ, Kappel CV, Wolanski E. 2009. Non-linearity in ecosystem services: temporal and spatial variability in coastal protection. Front Ecol Environ 7: 29-37.

Komiyama A, Poungparn S, Kato S. 2005. Common allometric equation for estimating the tree weight of mangroves. J Trop Ecol 21: 471-477.

Kumar P, Muradian R. 2009. Payment for ecosystem services and valuation: challenges and research gaps. In: Kumar P, Muradian R (eds) Payment for Ecosystem Services. Oxford University Press, Oxford, UK

Kusmana C. 1993. The current status of mangrove forest management in Indonesia. Faculty of Forestry, Bogor Agricultural University, Bogor.

Kusmana C. 2014. Distribution and current status of mangrove forests in Indonesia. In: Faridah-Hanum I, Latiff A, Hakeem K, Ozturk M. (eds) Mangrove Ecosystems of Asia. Springer, New York.

Lange GM. Jiddawi N. 2009. Economic value of marine ecosystem services in Zanzibar: Implications for marine conservation and sustainable development. Ocean Coast Manag 52: 521-532.

Lipton DW, Wellman K, Sheifer IC, Weiher RF. 1995. Economic valuation of natural resources. A handbook of coastal resource policy makers. NOAA Coastal Ocean Program Decision Analysis Series No. 5. NOAA Coastal Ocean Office, Silver Spring, MD, USA.

LPP Mangrove. 2000. Draft strategi nasional pengelolaan ekosistem mangrove Indonesia. LPP Mangrove, Bogor. [Indonesian]

MA. 2005 Ecosystem and human well-being: Synthesis. Millennium Ecosystem Assessment. Island Press, Washington, DC.

Mazda Y, Magi M, Kogo M, Hong PH. 1997. Mangroves as a coasta protectionfrom waves in the Tong King Delta, Vietnam. Mang Salt Marshes 1 (2): 127-135.
MMAF (Ministry of Marine Affairs and Fishery). 2017. Indonesia marine and fisheries in numbers. Misnistry of Marine Affairs and Fisheries. Jakarta. [Indonesia]

Mojiol AR, Guntabid J, Lintangah WJ, Ismenyah M, Kodoh J, Chiang LK, Sompud J. 2016. Contribution of mangrove forest and socioeconomic development of local communities in Kudat District, Sabah Malaysia. Intl J Agric Plant 2: 123-129

Mudiyarso D. 1999. Perlindungan atmosfer melalui perdagangan karbon: Paradigma baru dalam sektor kehutanan. Orasi ilmiah guru besar tetap ilmu Atmosfer. Fakultas MIPA IPB. Bogor. [Indonesian]

Murray BC, Pendleton L, Sifleet S. 2011: State of the science on coastal blue carbon: A summary for policy makers. Nicholas Institute for Environmental Policy Solutions Report NIR 11-06.

Nagelkerken I, Blaber SJM, Bouillon S, Green P, Haywood M, Kirton LG, Meynecke JO, Pawlik J, Penrose PM, Sasekumar A, Somerfield PJ. 2008. The habitat function of mangroves for terrestrial and marine fauna: A review. Aq Bot 89: 155-185.

National Research Council (NRC). 2004. Valuing ecosystem services: toward better environmental decision-making. The National Academic Press, USA.

Noor YR, Khazali M, Suryadiputra INN. 2006. Panduan Pengenalan Mangrove di Indonesia. PHKA/WI-IP. Bogor.

Odum EP. 1998. Dasar-dasar ekologi (terjemahan). Edisi II. Gadjah Mada University Press. Yogyakarta. [Indonesian]

Pendleton L, Donato DC, Murray BC, Crooks S, Jenkins WA, Sifleet S, Craft C, Fourqueran JW, Kauffman JB, Marbà N, Megonigal P, Pidgeon E, Her D, Gordon D, Balder A. 2012. Estimating global "blue carbon" emissions from conversion and degradation of vegetated coastal ecosystems. PLoS ONE 7 (9): e43542. DOI: 10.1371/journal.pone.0043542.

Permen KLH. 2012. Peraturan Menteri Negara Lingkungan Hidup Republik Indonesia nomor 15 tahun 2012 tentang Panduan Valuasi Ekonomi Ekosistem Hutan. [Indonesian]

Peters-Stanley M, Hamilton K, Yi D. 2012. State of the Forest Carbon Market: Leveraging the Landscape State of the ForestCarbon Markets 2012. Forest Trends, Washington DC

Pramudji. 2001. Ekosistem hutan mangrove dan peranannya sebagai habitat berbagai fauna akuatik. Oseana XXVI (4): 13-23. [Indonesian]

Robbins A. 2005. Ecosystem Services Market. University of Washington, Seattle WA, USA.

Ruitenbeek HJ. 1992. Mangrove management an economic analysis of management option with a focus on Bintuni Bay, Irian Jaya. EMDI Environmental Report. Jakarta.

Samonte-Tan G, Armedilla MC. 2004. Economic valuation of Philippine coral reefs in the South China Sea Biogeographic Region. National Coral Reef Review Series No. 3. UNEP, Bangkok.

Sathirathai S, Barbier EB. 2001. Valuing mangrove conservation in Southern Thailand. Contemp Econ Policy 19 (2): 109-122.

Seenprachawong U. 2004. An economic analysis of coral reefs in the Andaman Sea of Thailand. In: Ahmed M, Chong CK, Cesar HJS (eds) Economic valuation and policy priorities for sustainable management of coral reefs. WorldFish Center Conference Proceedings 70, Penang, Malaysia.

Soegianto A. 1994. Ekologi Kuantitatif: Metode Analisis Populasi dan Komunitas. Penerbit Usaha Nasional. Surabaya. [Indonesian]

Soerianegara, I, Irawan A. 2002. Ekologi Hutan Indonesia. Laboratorium ekologi hutan Fakultas Kehutanan. Institut Pertanian Bogor. Bogor.

Sondak CFA, Ang PO, Beardall J, Bellgrove A, Boo SM, Gerung GS, Hepburn CD, Hong DD, Hu Z, Kawai H, Largo D, Lee JA, Lim PE, Mayakun J, Nelson WA, Oak JH, Phang SM, Sahoo D, Peerapornpis Y, Yang Y, Chung IK. 2016. Carbon dioxide mitigation potential of seaweed aquaculture beds (SABs). J Appl Phycol. DOI: 10.1007/s10811-016-1022-1.

Sondak CFA, Chung IK. 2015. Potential blue carbon from coastal ecosystems in the Republic of Korea. Ocean Sci J 50:1-8

Spalding MD, Blasco F, Field CD. 1996. World Mangrove Atlas. International Society for Mangrove Ecosystems. Okinawa, Japan.

Spalding MD, McIvor AL, Beck MW, Koch EW, Möller I, Reed DJ, Rubinoff P, Spencer T, Tolhurst TJ, Wamsley TV, van Wesenbeeck BK, Wolanski E, Woodroffe CD. 2014. Coastal ecosystems: a critical element of risk reduction. Conserv Lett 7: 293-301.

Spurgeon JJ. 2002. Socio-economic assessment and economic valuation of Egypt's mangroves: rehabilitation, Conservation and sustainable utilization of mangroves in Egypt. Working Paper-FSFM/VAL/02. FAO, Rome. 
Takarendehang R, Sondak CFA, Kaligis EY, Kumampung D, Manembu IS, Rembet UNWJ. 2018. Kondisi ekologi dan nilai manfaat hutan mangrove di Desa Lansa, Kecamatan Wori, Kabupaten Minahasa Utara. Jurnal Pesisir dan Laut Tropis 2 (1): 45-52. [Indonesian]

TEEB. 2010. The economics of valuing ecosystem services and biodiversity. Kumar P. (ed.). Earthscan, the Ecological and Economic Foundations, London.

Tong CF, Feagin RA, Lu JJ, Zhang XF, Zhu XJ, Wang W, He WS. 2007. Ecosystem service values and restoration in the urban Sanyang wetland of Wenzhou, China. Ecol Eng 29: 249-258

Vasquez JA, Zuniga S, Tala F, Piaget N, Rondriquez DC, Alonso-Vega JM. 2014. Economic valuation of kelp forests in northern Chile: values of goods and services of the ecosystem. J Appl Phycol 26: 1081-1088.

Vo QT, Kuenzer C, Vo QM, Moder F, Oppelt N. 2012. Review of valuation methods for mangrove ecosystem services. Ecol Indic 23: 431-446.
Wahyudin Y. 2007. Economic value of natural seaweed beds resources along Ujung Kulon Banten Coast. http://ssrn.com/abstract=1678973 . [Indonesian]

Wattage P. 2011 Valuation of ecosystem services in coastal ecosystems: Asian and European perspectives. Ecosystem Services Economics (ESE). Working Paper Series No. 8. The United Nations Environment Program, Bangkok.

Wilson MA, Costanza R, Boumans R, Liu S. 2005. Integrated assessment and valuation of ecosystem goods and services provided by coastal systems. In: Wilson JG (ed.). The Intertidal Ecosystem: the Value of Ireland's Shores. Royal Irish Academy, Dublin.

Woodward RT, Wui YS . 2001. The economic value of wetland services: a meta-analysis. Ecol Econ 37: 257-270

Yanagisawa H, Koshimura S, Goto K, Miyagi T, Imamura F, Ruangrassaee A, Tanavud C. 2009. The reduction effects of mangrove forest on a tsunami based on field surveys at Pakarang Cape, Thailand and numerical analysis. Estuar Coast Shelf Sci 81 (1): 27-37 